\title{
RELIGION AND AFRICAN VALUES: EXPLORING THE SUPERNATURAL FORCES IN ELECHI AMADI'S THE CONCUBINE
}

\author{
${ }^{1}$ Agbonifo Rosemary and ${ }^{2}$ Emoga Ovekaemo \\ $1 \& 2$ Department of Arts and Humanities, \\ Delta State Polytechnic, Ozoro, Nigeria. \\ ${ }^{1}+2348167195145,{ }^{2}+2348069298514$ \\ Email: rossyagbonifo123@gmail.com
}

\begin{abstract}
In the African Society, everything revolves around their superstitious beliefs customs, traditions, culture and their religious values. The African philosophy, specifically Nigerian belief is grounded in African traditional religions. Ordinarily, the Africans have certain beliefs in the supernatural and in the erratic nature of the gods, they believe in the powers of the ancient myths, legends, rituals, primordial images, that is powers and forces that existed from the beginning of time, they believe in spirits, ghost, mystical forces, gods and goddesses, they also have a very strong believe in mystical powers, unforeseen forces and the reoccurrence of events. However, this paper is exploring the supernatural forces in Elechi Amadi's The Concubine with regards to religion and African values. The roles and influence of the supernatural agents in the work of arts that existed from the beginning of time are also traced and exposed in this paper. Findings from the study indicate that, all Africans are basically connected to their ancestral powers through the worship of their gods and forefathers via the pouring of libations, divinations and enchantments. This paper therefore posits that although human beings have commonalities that transcend cultures, they also have specific personality traits that are influenced by the supernatural forces that reside in the subconscious.
\end{abstract}

Keywords: Religion, African values, Supernatural forces, gods, Tradition. 


\section{INTRODUCTION}

This paper has religious background or identity, because from many sources, it views human life as that which is controlled by a superior being. In Africa, we have a set of beliefs and customs, these beliefs and customs often go together, some people say that God did not only create the material universe; He also established laws of nature and human customs, He also ordained the destiny of His creatures especially that of man which is in the researcher's own point of view that "What will be will be!"

Amadi's world lies prostrate under the supreme force of theological determinism and events which serve to stress 'the fatalistic insignificance of man' (Dathorne, 104). This type of absolute fatalism introduces problems of characterization since, as Niyi Osundare observes with reference to The Concubine rather than act, the characters are acted upon. The sea-god manipulated his human puppets and does not for one moment let go of the strings (101). In Amadi's work, two dimensional characterizations replace the rich complexity and grandiose heroism offered in Achebe's works. For example, Ihuoma's sea-goddess perfection works against the universality of her tragedy, since she is not a true testament of subordinate man in his perpetual struggle against blundering fate. She is too perfect to be a tragic figure in the classical sense.

In addition, Amadi's characters crumbling under the overwhelming weight of Ogbunabali, the night death-god or the irresponsible and the vindictive sea-god, exude pathos, not heroism. It is true we are shown the people's vitality amid love of life despite all pervasive suffering, but the evocation of these qualities serves only in contrast to deepen the pathos and sense of loss.

The people's deep sense of religion and superstition serve to strengthen the fatalistic frame work. There is the story of Ogonadi who tries to make rain in rivalry with Nwokekoro, the priest of Amadioha, the god of thunder, he had been struck down by a thunder-bolt, while collecting herbs by the wayside. This, we are told all went to confirm that a man cannot wrestle with the gods (Amadi 9). The belief is that of a subserviently religious people trembling under the ever-present tyranny of fearsome gods. Niyi Osundare points out that the sea king in The Concubine is cold, indifferent, manipulative, unappeasable, more Olympian than African and with Ogbunabali of The Great Ponds rules through fear and intimidation (107). Alastair Niven (187), talks of their implacable and almost Euripidean indifference, while Margaret Lawrence likens them to the unjust gods of ancient Greek (181). Through the realistic presentation of the supernatural, Amadi raises their status to that of active protagonist. For most of the novel, the author assumes the credulous voice of a village raconteur, events abound where no alternatives are provided as possible natural explanations.

The intervention of the supernatural is thus authentic and raised beyond the level of a due ex machina. It is in fact an attempt to explain away these as incidental, natural, social or psychological occurrences that would appear ridiculous. Possible natural alternative explanations seem provided only to highlight their implausibility.

The stronger argument always lies with the supernatural explanations. The supernatural scenes are presented in such detail that a strong impression of truth is given. There is for example, the strange transformation of the Amadioha priest, Nwokekoro at the shrine and his uncanny ability to command Ekwueme to speak during his mental illness (Amadi, 17). 
Amadioha is presumably physically present at the shrine in form of a huge gray serpent. The sea-god is shown as having character traits, like jealousy and ostentations common to human protagonist. There are the astonishingly accurate divinations of the dibias, often confirmed by other dibias. Anyika's revelation that Ihuoma is a water spirit is confirmed by Agwoturumbe, a dibia in Alija, another village.

There are also astonishing similarities in detail (199). We easily accept Emenike's death by the lock-chest at first and the blinding Madume's big eye which cost him his life eventually. Niyi Osundare in his essay titled As Grasshoppers to Wanton Boys is based on Ihuoma's second child who has caught some grasshoppers and was feeding them limb by limb to some ants. He watched with undivided attention, the way the ants dragged their comparatively mighty burdens into the dark mysterious interior of their holes (p 107). The helplessness of these insects, the desperate hut fruitful bid for freedom is a power analogue to the plight of humans in the hands of the gods, they kill us for their sport and at will.

This is why Ihuoma nurses irreverent thoughts after her husband's death (21) when Ekwueme goes mad, his father point out that they have never missed a sacrifice (17). There is in Amadi's work a recurrent theme of the futile sacrifice in The Great Ponds. It is Olumba whose personal motto is: I would rather face a whole village in battle than have the weakest of the gods after me and he who never fails to offer sacrifices to the gods that is first marked out for unmitigated suffering (Amadi, 17).

In The Concubine Ekwueme had a dream in which the dead Emenike bids him a stream, he refuses, but he is dragged across by other villagers. Similarly, Madume's inglorious end is heralded by an ominous toe injury he sustains while attempting to court Ihuoma. Anyike the dibia, hints that spirits from the sea are among those that cause the injury. In fact, their plan had been to destroy him there and then. Later the researcher discovers that Ihuoma in her former life had been a sea goddess and is thus, jealously guarded by the sea-king in her present life, with fatal consequences for any man who attempts marrying her.

Eustace Palmer (1966:3) says that Amadi has rendered his supernatural elements credible, convincing and acceptable by showing the sea-gods as not only having numerous wives, he also determines the human beings he chooses as a sacrificial lamb. Esslin (1979:2123) says that any dramatist has to feel a greater commitment to his primary rather than his international audience.

Dravidians discovered among the Scottish Celts, that their belief in supernatural was strong, according to him; they believed that the human life was regarded by them to be encompassed and ruled by an over mastering destiny from which there was no possibility of escape.

Soyinka (1976:3) describes the union and co-operation between the human and the divine as cosmetic totality relationship compounded by fellow and supernatural, a relationship that is particularly vital for the African world-views.

Taiwo (1976:204) concludes that The Concubine is concerned with the circumstances of marriage, which ends in disaster for reasons, which are deeply human and universally valid. Bolaji (1978:2) also traces the source of the tragedy in The Concubine, to ...an attempt by individuals and communities to prevent the course of order and the accepted norms in the 
society. He goes further to say that Ekwueme's madness and subsequent death are necessary punishment for his attempt to upset social order, but still it is hard to say what social aspect order Ekwueme's has upset to warrant his death, marrying a widow is not the crime that Bolaji makes it out to be. Taiwo and Bolaji have tried to attribute human tragedy in Amadi to a kind of hamartis.

It is therefore believed that the supernatural exists and it is that ruling force or power which cannot be explained by humans or laws of science which seems to involve gods or magic, this belief therefore cannot be uttered by human; therefore human beings have been bestowed before their birth by the gods of what becomes of them in life.

Africans however, deny the possibilities of chance as they feel that the future of the individual and the world as a whole is already laid down by the supernatural forces and human' individual actions have no effect on it.

\section{Objectives}

The main objectives of this study are:

i. To expose the barbaric practices of the African communities with regards to their cultures, myths, traditions, religions, legends, rituals and history and at the same time to proffer a solution to those ill practices.

ii. To expose the strong body-feeling attraction that could lead to extreme pleasure, happiness and finally destruction as a result of the erratic nature of the supernatural forces in the African setting.

iii. To highlight on the roles and influence of the supernatural agents in the work of Arts, the African ways of life, their beliefs, norms and morals according to Elechi Amadi's work.

\section{Analysis Of The Concubine In Relation To Religion (Gods, Goddess, Spirits, Supernatural Forces) And African Values}

According to the Chambers 21 Century Dictionary, the term spiritual means belonging, referring or related to the spirit or soul rather than to the body or to the physical things. It also means belonging, referring or relating to religion; sacred, holy or divine, it is also referred to as spirits, ghosts etc.

The Oxford Advanced Learner's Dictionary described supernatural as that which cannot be explained by the laws of science and seems to involve gods or magic."

All over the world, the idea of the supernatural is overwhelming. In the ancient Greek literature, man is presented as being subservient to supernatural forces or the gods. This idea of superiority of the gods is also carried over by the English. In Christopher Marlowe's Dr. Fastus, there is the overwhelming weight of fate that governs the life of the characters in the story. No matter what the characters do, they are still subjected to and manipulated by the gods.

In Africa before the coming of the European, there is also a belief in the supernatural powers. In relation to these gods or goddess, man is bound to serve these gods and render sacrifices to them. But there is exception, in case of a non performing god or goddess, either 
that god is thrown away, burnt or left without sacrifice. Therefore, the relationship between man and the gods is that of mutual trust and motivation either for reward or punishment.

When a man renders the usual sacrifice and does everything the gods proposes, and then he expects and often gets prosperity in health and wealth, but the gods has no right to withdraw its reward when the worshipper is not in the wrong. When this happens, it means there is a break in the spirit realm or in the supernatural order.

In The Concubine, the supernatural forces are presented in a hierarchical order. There are the dibias who are above man in the society. Though, they are men that live among others in the society, they have an ability that puts them above other men. This is the ability to divine pronouncements of the gods and interpret them. They therefore serve as spokesmen of man in his relationship with the gods. Among these men are Anyika and Agwoturumbe. Slightly higher than the dibias, are the priests of various gods. They are the intermediaries between man and the gods. After man has gotten a message from the gods, he will want to appease a certain god, he or she can only do this through the services of a priest. In this rank is Nwokekoro the chief priest of Amadioha. Then above all are the gods, they are many and there is division of labour among them. Amadioha is the god of the sky, while Ojukwu is the god of disease and especially a controller of smallpox. In this order, peace is maintained as man and the gods live together through consultation and appeasement.

However, in the story line, the forces behind the supernatural order render the reader speechless. Even the characters of the story are in a state of dilemma. This is because: the gods are no longer appeased through sacrifice. At a time, even the sacrifice to the gods compounds the problems of these characters. There are three ways in which the novelist ruptures the supernatural order in the novel. One way in which the paper highlights on the supernatural order in the novel is through the physical combat between Emenike and Madume. Emenike who is the husband to Ihuoma, is described as.

"Slight of build but well proportioned" and ranked as an average wrestler. On the other hand, Madume "had a narrow square head (axe-head according to villagers) and an Iroko trunk. Worse still he had a temper as bad as that of a man with whitlows on his ten fingers" (Amadi 1).

The fight between the duo results from a quarrel (over a piece of land). The elders of the village had earlier given the land to Emenike in their judgment. But Madume will have none of it and he went and ambushed Emenike. During the duel, Emenike sustained internal injury. Emenike, due to his injuries fell sick to the point of dying. The dibia is then summoned to consult his oracle. Anyika, the village dibia treated Emenike. Emenike recovered gradually. After his full recovery, he decided as is the custom to render a sacrifice to Amadioha, the god of thunder and of the sky, whose priest is Nwokekoro. This is because Amadioha is merciful to him. The contrast according to the novelist would have been death. In the words of the novelist, it is a fact that if Amadioha insisted on taking a man's life, no medicine man could do anything about it and only a medicine man of great confidence would dare to try (Amadi 9).

This implies that the gods does not want Emenike dead. Emenike's recovery therefore reassures the villagers and the priest that all is well with him and the gods. The acceptance of Emenike's sacrifice to Amadioha through the swallowing of the chicken part by the huge grey serpent representing Amadioha was a great proof to the villagers that Emenike is 
favoured by the gods. However, after the sacrifice, Emenike died suddenly and mysteriously. So, the question is: what is the cause of Emenike's death? Is it because of the physical fight, the injuries sustained or the handiwork of the gods? The answer is given by Anyika, the dibia that Emenike: Apparently died of 'lock-chest' but actually it was all the design of the sea king. As soon as Emenike married Ihuoma his life was forfeited and nothing would have saved him (195).

Apparently, it is the supernatural forces that killed Emenike. But was it not the same supernatural forces that treated Emenike to recovery and even accepted his sacrifice? Why would they accept his sacrifice only to kill him afterwards? Why did they lure him to physical combat first? Can't they just kill him with any supernatural element like thunder or even a falling tree or house?

These questions can only lead to one interpretation, the novelist has ruptured the supernatural order of things in the story, this is due to the fact that Emenike would have died earlier and the explanation would have been that of a lock-chest,' but the mysteriousness of the death renders it as a result of supernatural forces which are erratic.

Another way the researcher describes the supernatural order in The Concubine is through human folly. Human beings are not perfect characters, they sin all the time, but whenever this happens, if the individual is aware of his misgivings, he or she goes to the gods, confesses before them and is forgiven. Then, a sacrifice is given for the forgiveness of sin, but in certain cases, when the individual is stubborn or even ignorant, then the gods punishes the individual through sickness, accident or even death. No matter the situation, a sacrifice is also rendered to appease the gods to withdraw their wrath.

In the story, Madume is a character with a flaw. He is greedy or 'big-eyed, he covets Emenike's land to his, even when the elders of the village decided in their judgements that the land belongs to Emenike, Madume's greed will not restrain him, he fights Emenike. Later Emenike died, and after the death of Emenike, Madume begins to eye Ihuoma, Emenike's widow. In his attempt to flirt with Ihuoma, Madume hit his toe against 'the protruding corner of an old hoe half buried in the ground. His big toe nail came off and he cried out in pain' (Amadi 57). Madume understands that something is wrong somewhere. This is because there is a suspicion in his mind that covetousness is a sin. Moreover, lifting a toe against an obstruction is superstitious. It is either for bad or for good. So, the next thing to do is to consult the oracle.

The news from the oracle is frightening but favourable. The gods wanted to destroy Madume, they have to be appeased. The efficacy of the sacrifice is attested to by Anyika, the dibia when he says: Trust Chineke who is the creator of spirits and men. Without Him my divinations are void (Amadi 59).

Later, the confidence of Madume after the sacrifice is testified to by the narrator of the story that:

Now he was confident that no roving malevolent spirits would disturb him. Anyika was a dibia indeed. He thought of Ihuoma ....and the land in dispute? No. he would never give that up. Indeed he felt he should now establish his claim to ownership once and for all (Amadi 67). 
Madume's confidence in the sacrifice of Anyika led him to covet the land and its fruit. But Ihuoma stands in the way. Madume brushed her aside only to be spat on by a cobra, Madume's eyes became swollen. Once again, Anyika is sought for, he divined that a suitable sacrifice will have to be rendered before treatment could commence. The sacrifice is carried out. Still, Anyika's treatment bore no fruitage, for Madume became totally blind.

Once again, the novelist has ruptured the supernatural order of things. The same question begins to reverberate. The gods are heartless, they will accept a sacrifice. They even reveal the situation to Anyika correctly, Anyika also prescribe the correct sacrifice equivalent to the sin which eventually leads to a state of equilibrium. The gods then in accepting the sacrifice are promising a reward of good health and wealth which is the normal order of the supernatural. But, then suddenly, without warning, they strike the individual in a way that will render him helpless and speechless. The question then is: why will the gods accept a sacrifice, only to kill the patient afterwards? The explanation lies in the powers/forces of the supernatural order by the novelist.

Lastly, the novelist describes the supernatural order in the story through the use of the weapon of love. Love is universal. Even in the Bible, I Corinthians 13:8 states that 'Love never fails. It is the love man has for the gods that moves them to worship and render sacrifices to them. In return, the gods love for man is manifested in abundant rainfall and good harvest. But when the reverse is the case, then both man and gods suffer. This is because, when there is no rainfall, harvest will be hard and sacrifice will become scanty.

However in The Concubine, love becomes the weapon of death in the hands of the gods. In the first instance, love acts to capture the supernatural order of things in the supernatural realm. This is the case of Ahurole. Ahurole is the wife of Ekwueme, She is young and beautiful, but she nags too much. This flaw in bet personality is mostly because of her young age and childish in nature. This leads her husband to seek solace in the maturity of Ihuoma. Ahurole takes this for a case of losing her husband, she therefore confides in her mother, Wonurna. They, as usual went to the dibia. Anyika advised them against using a love portion to win the love of Ekwueme. Desperate for supernatural means, a medicine man at Chiolu prepared one for them. At the end, instead of the portion to supernaturally increase Ekwueme's love for Ahurole, it makes Ekwueme go mad with love for Ihuoma. Ahurole who is too flabbergasted runs away to her parent's home. How could a love portion that will make Ekwuene love Ahurole turn to madness and a longing for Ihuoma on the part of Ekwueme? This indeed is a rupture of the supernatural order of things.

Another instance where love contributes to the erratic nature of the supernatural order in Elechi Amadi's The Concubine is during the preparation to cast a spell to blind the sea-king god. Ekwueme' disposition toward Ihuoma and the fact that her love is soothing to him makes the marriage inevitable, but there is a road block. According to Anyika the dibia;

Ihuoma belongs to the sea. When she was in the spirit world she was among the ruling spirit of the sea. Against the advice of the sea-king, her husband she sought the company of human beings and incarnated. The sea-king was very angry but because he loved her best of all his wives he did not destroy her immediately she was born. However, because of his great love for her he is terribly jealous and tries to destroy any man who makes love to her (195). 
This impediment can somehow be circumvented. Ekwueme's family trust in Anyika the dibia began to evaporate in the face of the supernatural forces preventing Ekwueme and Ihuoma from loving each other. Ekwuerne and his father decided to go to Aliyi to consult another diviner. According to the narrator: In essence his divination was not much different from Anyika's, but by far the most important difference in his divinations was his assertion that he could bind the sea-king and prevent him from doing any harm (Amadi 199).

Agwoturumbe's reputation as a dibia is known far and wide. This divination must surely be from the gods. This idea is replenished by the ovation of welcome and the mutual respect Anyika had for Agwoturumbe. The efficacy of this sacrifice is not in doubt, for it would have blinded the sea-king, but that is not to be. Before the sacrifice, Ekwueme is struck by a flying arrow from the bow of Nwoma, the son of Ihuoma. Everyone is dejected. Why? This is the only question in the mouth of the people. According to the narrator: The spirit of death was known to take away people's souls shortly after midnight. That was when Ekwueme died (216).

So, no matter the sacrifice, the gods are always exacting their pound of flesh from the characters in the story. The more the sacrifice, the more penalties the sacrifice pays. In all, this paper has succeeded in exploring the supernatural order in the story. The characters are almost perfect, they always consult the dibias, and they always render whatever sacrifice the gods ask for. But in the end, they are punished severely. This makes Nyi Osundare, in his essay "As Grasshoppers to Wanton Boys: The role of the gods in the novels of Elechi Amadi" to conclude that: In fact, human characters here are so good that the gods look bad for causing them unnecessary suffering. What we have, therefore, is not human but divine harmartia (102).

Therefore, instead of the natural order that is not balanced, in The Concubine, it is the supernatural order that is rupture. The gods in the story are not working according to the supernatural order of balance between sacrifice and reward or sin and punishment. They reward sacrifice with punishment.

\section{Conclusion}

Recreated in The Concubine is a rural setting in which traditional African culture and religious value are explored. The people's very existence revolves around their communion with the gods, traditional marriages, hunting and Sunday evening merriments. Amadi recreates a typical African society that is ruled by the gods. In fact, according to Adewoye Sam, the people live their lives under the superintendence of the gods whose powers are based on traditional myths (77).

The gods are powerful presence among the people. They are said to determine a person's destiny or fate. In Africa, this idea of overwhelming gods is also portrayed in Ola Rotimi's, The gods are not to blame. King Odewale could not escape his fate.

However, in The Concubine, the gods were not portrayed as rigid who seal people's fate and then watched them suffer and gradually end up in their fate. If this is the case, then the people of Omakachi would have no need of rendering sacrifices and observing laws and customs promulgated by the gods. The yearly festivals and sacrifices are meant to appease 
the gods, seek their favor, and alert them to protect the people and avert the sad fate awaiting them. This is the situation at the beginning of the story.

In contrast, the story ends with the view that the gods, especially the sea-king cannot be placated. Thus, no matter what sacrifice is rendered; the gods remain steady and unmoved in their bid to kill their victims. This is the supernatural rupture in the story. The gods who had hitherto been placated were now not being pacified by the same sacrifice. This study has therefore highlighted the erratic nature of the gods. The gods or supernatural forces in refusing to be placated now expose themselves to destruction. This is due to the fact that is it their flexibility that creates awe in their worshippers. A god who cannot accept sacrifice is no longer useful. So, in destroying their victims, the gods are rendering themselves irrelevant.

Secondly, this study also discovered that supernatural forces and powers only exist in the mind of their adherents. As far as sacrifices are no longer changing the circumstances of the characters in the story, it means the gods are not even in existence. Collaborating this point, the boatman who is supposed to take Ekwueme to the river says: Well, you see, people often said they saw the sea-king, but I never saw him myself. I always felt the medicine men were deceiving them (Amadi 212).

This is the most important lesson derived from this study. The gods only exist in the figment of imagination of their worshippers. This study is therefore important in the separation of religion from secular authority. A progressive state will be one where, the supernatural forces are not allowed to dictate the pace of development.

Conclusively, thanks must go to Elechi Amadi for objectively presenting the place of the supernatural if we must develop. He urges caution as swallowing all their dictates will lead to tragedy. The tragedy of Ekwueme is then a summon from Amadi that we must be objective and pragmatic. In the words of Omafume Onoge in his essay, "Crisis of consciousness in African Literature":

The African writer has already surpassed the majority of his class colleagues in telling us where we came from and where we are at present. If he is to complete the task by telling us where we are going, he must be prepared to commit class suicide (Onoge, 44). The powers/forces of the supernatural is Amadi's own way of doing that.

\section{RECOMMENDATION}

It is therefore recommended amongst others that:

i. Religion should be based on a mutual agreement with the supernatural: if they help man, then they will eat enough sacrifice. But when they afflict man then, they should by left outside in the rain to melt away.

ii. Policy makers in our country today should take care not to put their development plans entirely in the hands of the supernatural.

iii. The supernatural are erratic. Pragmatism is the way forward.

iv. Man should not easily fall in love with the worship of the supernatural forces as they may likely deceive and disappoint man at any given time. 


\section{Works Cited}

Achebe, Chinua. Hope and Impediments. New York: Doubleday, 1989.

...Morning yet on Creation Day. London: Heinemann, 1975.

...Things Fall Apart. London: Heinemann, 1958.

Adeoye Sam. The African Novel (Another Evaluative View. Ilorin: Majab publishers 1996.

Amadi, Elechi. The Great Ponds. London: Heinemann, 1970.

...The Concubine, London: Heinemann, 1973.

Bolaji, Idowu E.B. Culture and Communication in the novels of Elechi Amadi (Unpublished paper): Ibadan, 1978.

Chambers $21^{\text {st }}$ Century Dictionary. Edinburgh: Chambers Harrap Publishers, 1996.

Dathorne, Oscar. African Literature in the Twentieth Century. London: Heinemann. 1982.

Drabble, Margret and Jenny, Stringer. The Concise Oxford Companion to English Literature. London: Oxford Press. 2007.

Ebele. Eko, Elechi. Amadi. The Man and His works. Lagos: Kraft Books, 1991.

Emenyonu Ernest. Studies on the Nigerian Novel. Ibadan. Heinernann. 1991.

Lattimore. Richmond. Story Patterns of Greek Tragedy. Ann Arbor, Michigan: Ann Arbor Paperbacks. 1969.

Niven, Alastair. The Achievement of Elechi Amadi. Research in Africa Literatures. Vol. II, No. 1, 1971.

Obiechina, Emmanuel. Culture, Tradition and Society in the West African Novel. London: Cambridge University Press, 1975.

Ola, Rotimi. The Gods Are Not To Blame. London: Oxford University Press, 1971.

Onoye. Omafume. Crisis of in African Literature. Trenton N.J: African World Press, 1985.

Osundare, Niyi. As Grasshoppers to Wanton Boys: The Role of the gods in the novels of Elechi Amadi. London: Heinemann Educational Books, 1980.

Oxford Advanced Learner s Dictionary. 7th Edition: international Student's Edition. India: Oxford University Press, 2006.

Palmer, Eustace. An Introduction to African Novel. New York: African publishing Co. 1966. 
International Journal of Advanced Academic Research (Arts, Humanities and Education) | ISSN: 2488-9849

Journal DOI: 10.46654/ij.24889849

Vol. 6, Issue 9 (September, 2020) | www.ijaar.org

Article DOI: 10.46654/ij.24889849.a694

Soyinka, Wole. Myth, Literature and the African World. Cambridge: Cambridge University Press, 1976.

Wikipedia Online Encyclopedia. 2014. 